\section{Influence of Poly-L-Lactic Acid Scaffold's Pore Size on the Proliferation and Differentiation of Dental Pulp Stem Cells}

Marcus Cristian Muniz Conde ${ }^{1}$, Flávio Fernando Demarco ${ }^{1}$, Luciano Casagrande ${ }^{2}$, José Carlos Alcazar ${ }^{1}$, Jacques Eduardo Nör ${ }^{3}$, Sandra Beatriz Chaves Tarquinio ${ }^{1}$

\author{
'Post-Graduate Program in \\ Dentistry, Dental School, \\ UFPel - Federal University of \\ Pelotas, Pelotas, RS, Brazil \\ ${ }^{2}$ Department of Oral Surgery and \\ Orthopedics, Dental School, UFRGS \\ - Federal University of Rio Grande \\ do Sul, Porto Alegre, RS Brazil \\ ${ }^{3}$ Department of Cariology, Restorative \\ Sciences and Endodontics, Dental \\ School, UMICH - University of \\ Michigan, Ann Arbor, MI, USA
}

Correspondence: Marcus Cristian Muniz Conde, Rua Gonçalves Chaves, 457, $5^{\circ}$ andar, 96015-560 Pelotas, RS, Brasil. Tel:+55-53-3225-6741.

\begin{abstract}
The aim of this study was to evaluate the influence of the poly-L-lactic acid (PLLA)based scaffold's pore size on the proliferation and differentiation of dental pulp stem cells (DPSCs). The scaffolds were prepared in pulp chambers of 1-mm-thick tooth slices from third molars using salt crystals $(150-250 \mu \mathrm{m}$ or $251-450 \mu \mathrm{m})$ as porogen. DPSC $\left(1 \times 10^{5}\right.$ cells $)$ were seeded in the scaffolds with different pore sizes, and cultured in 24-well plates. The cell proliferation was evaluated using the WST-1 assay after 3-21 days. Furthermore, RT-PCR was used to assess the differentiation of the DPSCs into odontoblasts, using markers of odontoblastic differentiation (DSPP, DSP-1 and MEPE). RNA from human odontoblasts was used as control. Cell proliferation rate was similar in both scaffolds except at the $14^{\text {th }}$ day period, in which the cells seeded in the scaffolds with larger pores showed higher proliferation $(p<0.05)$. After 21 days DPSCs seeded in both evaluated scaffolds were able of expressing odontoblastic markers DMP-1, DSPP and MEPE. In summary, both scaffolds tested in this study allowed the proliferation and differentiation of DPSCs into odontoblast-like cells.
\end{abstract}

e-mail: marcusconde82@gmail.com

Key Words: scaffolds, dental pulp, stem cells, tissue engineering, pore size.

\section{Introduction}

Odontoblasts are post-mitotic cells responsible for primary, secondary and reactionary dentinogenesis. After differentiation, they are no longer able to multiply, which limits the regenerative capability of the pulp $(1,2)$. Damage to dental pulp induces inflammatory responses with different degrees, corresponding to the nature and strength of injury (2). In pathological conditions, such as mild carious dentine lesions, odontoblastic activity is stimulated to elaborate reactionary dentine (3). However, in case of acute injuries by deep caries cavity preparations odontoblasts may be lost and dental pulp may undergo necrosis (4).

Traditionally, when pulp tissue undergoes necrosis, conventional endodontic therapy (CET) must be performed to remove the necrotic tissues (5). Despite the good results observed following endodontic therapy, in some situations CET may not be the first choice treatment (4).

Pulp necrosis in immature permanent teeth (IPT) occurs after trauma or untreated carious lesions (6). CET turns the root brittle, as IPT present discontinued root development with thin dentinal walls associated to the need of getting rid of dentin inside the pulp chamber, favoring the occurrence of root fracture in case of a new trauma. Also, there is an additional challenge to obtain an appropriated apical seal in IPT by applying CET (6). Currently, necrosed immature permanent teeth are subjected to multiple-visit apexification with $\mathrm{Ca}(\mathrm{OH})_{2}$-based materials to induce formation of an apical mineralized barrier $(6,7)$. Despite the good prognosis, the long-term $\mathrm{Ca}(\mathrm{OH})_{2}$-based apexification presents a series of drawbacks (8), such as multiple treatment appointments, probable recontamination of the root canal system during treatment and increased brittleness of the root dentin, which increases the risk of future cervical root fractures (7).

In this sense, the development of a new dental pulp by tissue engineering has produced increased interest (1). The three key elements of tissue engineering are responsive cells, knows as stem cells, morphogens or growth factors and scaffolds. Scaffolds are three-dimensional structures used to support and guide the ingrowth of cells, acting as an extracellular matrix (ECM) analogue (9). Dental pulp stem cells (DPSC) are multipotent stem cells able to differentiate into a wide range of tissues. Moreover, DPSC exhibit after odontoblastic stimulation (10), the expression of genes, dentin sialophosphoprotein (DSPP), dentin matrix protein 1 (DMP-1) and matrix extracellular phosphoglycoprotein (MEPE), related to the differentiation of stem cells towards an odontoblast-like cell phenotype (11).

Stem cell behavior relies on the scaffold's spatial properties such as porosity, pore size and void fraction (12). Scaffold's pore size has been shown to affect the cell 
attachment, proliferation, migration, morphology and gene expression $(10,13)$. The smaller the scaffold's pore size the greater the specific surface area for cell attachment on its surface; however, the cell migration can be hindered (12). Additionally, it has direct influence on the diffusion of nutrients and removal of waste into the scaffold, resulting in necrotic regions within the construct (14). On the other hand, the larger the scaffold's pores the easier the traffic of nutrients, gas diffusion and metabolic residue removal. However, it reduces the relative surface for cell attachment and a possible specific site as the integrin (14). Therefore, it is imperative for the future of dental tissue engineering to analyze physical characteristics of materials used to mimic the extracellular matrix.

The most favorable pore size range depends on the nature of the material and cell used in the constructs $(15,16)$. In poly-L-lactic acid (PLLA) scaffolds, vascular smooth muscle cells bind to a smaller pore range size (63$150 \mu \mathrm{m})$, while fibroblasts bind to a wider range (38-150 $\mu \mathrm{m})(15)$. In addition, for bone tissue engineering a range of pore sizes comprising 100-150 and 150-200 $\mu \mathrm{m}$ have shown substantial bone ingrowth, while a smaller range (75-100 $\mu \mathrm{m}$ ) results in the formation of an non-mineralized $\Xi$ osteoid tissue $(14,17)$. Besides, DPSC are able to attach and proliferate into PLLA scaffolds with a pore size ranging from 250-425 $\mu \mathrm{m}$, prepared in a tooth slice/scaffold (TS/S) model and produce a de novo pulp-like tissue $(10,18)$. Therefore, this study aims to evaluate the influence of PLLA scaffold's pore size on the proliferation and differentiation of DPSC using the TS/S model.

\section{Material and Methods}

\section{Chemicals}

Cell culture medium and reagents were supplied by Invitrogen (Grand Island, NY, USA). All the other reagents were obtained from Sigma Aldrich Chemical Co. (St. Louis, MO, USA), except for the phosphate buffered saline (PBS), which was purchased from Mediatech, Inc. (Herndon, VA,
USA) and the poly-L-lactic acid from Boehringer (Ingelheim, Germany).

\section{Cells}

Dental pulp stem cells (DPSC), gently provided by Dr. Songtao Shi (Dental Biology Unit, Craniofacial Skeletal Diseases Branch, NIH, Bethesda, MD, USA) were isolated by standard protocol (Gronthos et al., 2000). The cells were cultivated in Dulbecco's Modified Eagle Medium (DMEM) low glucose-containing 10\% fetal bovine serum and 1\% penicillin/streptomycin solution and incubated at $37{ }^{\circ} \mathrm{C}$ in $5 \% \mathrm{CO}_{2}$. During the experiments, cells from passage $4-6^{\text {th }}$ were used.

\section{Porogen Production and Tooth Slice/Scaffold (TS/S) Preparation}

Sodium chloride (salt) was sieved using metallic sieves producing two particle sizes: $150-250 \mu \mathrm{m}$ and $251-425 \mu \mathrm{m}$. After sieving, the salt was stored in Petri dishes until test. At the oral surgery clinic in the Dental School, University of Michigan, USA - noncarious human third molars were extracted from healthy and young patients (17-23 years old) after signing an informed consent and under an approved institutional review board protocol. Residual soft tissues were removed with a periodontal scalpel, and the dental surfaces were wiped with $70 \%$ ethanol. Teeth were transversely sectioned at the cervical region with a diamond blade at low speed under cooling with sterile phosphate-buffered saline (PBS) to obtain 1-mm thick tooth slices. The pulp tissue was thoroughly removed with sterile forceps and the dentin was conditioned for $1 \mathrm{~min}$ with ethylenediamine tetraacetic acid (EDTA) and washed again with PBS (18). Sodium chloride was sieved (150-250 $\mu \mathrm{m}$ and $250-425 \mathrm{~mm}$ ) and filled the pulp chamber. The tooth slices (1-mm thick) had their void pulp chamber (Fig. 1) filled with salt particles. The PLLA scaffolds were produced into TS/S using the solvent-casting/particulate leaching technique - SC/PL (19). Briefly, PLLA (Boehringer Ingelheim,
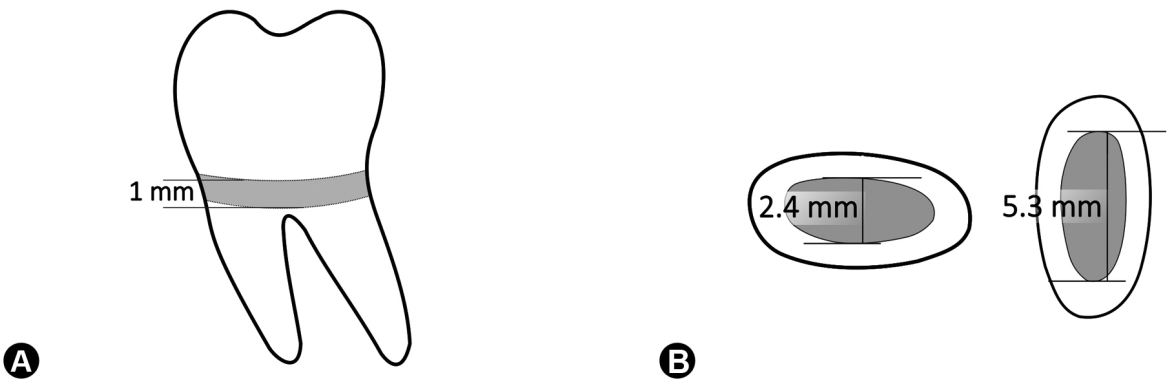

B

Figure 1. Diagram depicting the overall scheme for the model systems used here. A: 1-mm thick tooth slices were prepared from the cervical region of human third molars. B: Standardization of measures of the pulp chamber space into the tooth slices. 
Germany) was dissolved ( $5 \% \mathrm{w} / \mathrm{v})$ with chloroform, and the mixture was carefully dropped over the salt. After PLLA polymerization, the salt was leached with distilled water for $24 \mathrm{~h}$.

\section{Cell Seeding into TS/S}

DPSC at the subconfluent stage (80\%) were detached with $0.25 \%$ trypsin-EDTA and $1 \times 10^{5}$ cells in a $20 \mu \mathrm{L}$ cell suspension (DMEM) were seeded inside each $6 \mathrm{TS} / \mathrm{S}$ and placed in a 24-well plate. Immediately after seeding, samples were placed in incubator $\left(37^{\circ} \mathrm{C}\right.$ in $\left.5 \% \mathrm{CO}_{2}\right)$ for $1 \mathrm{~h}$ to allow initial cell attachment. Then, $500 \mu \mathrm{L}$ DMEM was added in each well, and the medium was changed every other day.

\section{Gene Expression}

To evaluate the relative gene expression was used the reverse transcriptase - polymerase chain reaction (RT-PCR). After 21 days in culture, three scaffolds per condition were pooled and total ribonucleic acid (RNA) was isolated and purified using the Trizol ${ }^{\circledR}$ system (Invitrogen) as recommended by the manufacturer (10). As control, odontoblasts were scraped from freshly extracted human third molars and RNA was isolated (20). Total RNA (0.2 $\mu \mathrm{g})$, from odontoblast and TS/S was used to perform the RT-PCR. The human-specific sense and antisense primers were designed according to published cDNA sequences of GenBank (Table 1). Three independent experiments were performed to verify the reproducibility of the results.

\section{Relative Cell Density (RCD)}

$\mathrm{RCD}$ in the TS/S was checked after 3, 7, 14 and 21 days

Table 1. Primer sequences and annealing temperatures applied for gene expression analyses

\begin{tabular}{|c|c|c|}
\hline $\begin{array}{l}\text { Relative } \\
\text { gene }\end{array}$ & Primer sequence (Genbank) & $\begin{array}{l}\text { Product size } \\
\text { forward }\end{array}$ \\
\hline GAPDH & $\begin{array}{c}\text { Forward } \\
\text { 5' GACCCCTTCATTGACCTCAACT 3' } \\
\text { Reverse } \\
\text { 5' CACCACCTTCTTGATGTCATC 3' }\end{array}$ & $683 \mathrm{bp}$ \\
\hline DSPP & $\begin{array}{c}\text { Forward } \\
\text { 5' GACCCCTTCATTGACCTCAACT 3' } \\
\text { Reverse } \\
\text { 5' TGCCATTTGCTGTGATGTTT 3' }\end{array}$ & $181 \mathrm{bp}$ \\
\hline DMP1 & $\begin{array}{c}\text { Forward } \\
\text { 5' CAGGAGCACAGGAAAAGGAG 3' } \\
\text { Reverse } \\
\text { 5' CTGGTGGTATCTTGGGCACT 3' }\end{array}$ & $213 \mathrm{bp}$ \\
\hline MEPE & $\begin{array}{c}\text { Forward } \\
\text { 5' GCAAAAGCACCCATCGTATT 3' } \\
\text { Reverse } \\
\text { 5' CTGCCCTCTACAAGGCTGAC 3' }\end{array}$ & 385 bp 15 \\
\hline
\end{tabular}

using the WST-1 dye (21). Briefly, at each time point, 20 $\mu \mathrm{L}$ WST-1 were mixed with $200 \mu \mathrm{L}$ of fresh DMEM medium and incubated during $1 \mathrm{~h}$ to develop the reaction. Then, an aliquot of $100 \mu \mathrm{L}$ was removed from each well and placed into a 96-well plate in order to evaluate the optical density of the formazan salts produced by the viable cells using an enzyme-linked immunosorbent assay (ELISA) multiplate reader (TECAN, Genius) with a wavelength filter of $450 \mathrm{~nm}$.

\section{Statistical Analysis}

Data from RCD were submitted to statistical analysis using two-way ANOVA followed by Tukey test using Sigmastat 2.0 software (SSPS, Chicago, IL, USA) and the significance level was set at $p<0.05$. For each condition/ time, triplicates were performed and the experiments were repeated at least three times.

\section{Results}

\section{Relative Cell Density}

Both pore sizes evaluated here produced similar RCD in the different test time-points. However, it was observed on the fourteenth day that RCD was higher in the scaffolds with larger porosities (Fig. 2). The cells in both scaffolds had a continuous growth up to 21 days, when a slight decrease was observed, indicating that the cells reached the confluence or differentiation.

\section{Gene Expression (RT-PCR)}

DPSC seeded in the TS/S with both pore sizes exhibited after 21 days the expression of all putative odontoblast markers (DSPP, DSP-1 and MEPE), similar to control. House-keeping gene was also expressed by control and experimental groups (Fig. 3).

\section{Discussion}

Both pore size ranges evaluated here produced similar effects on the DPSC proliferation and odontoblastic gene expression - DSPP, DMP-1 and MEPE (11). Considering the lack of information about this specific topic in the dental tissue engineering, it was chosen to evaluate the PLLA scaffold pore size over the proliferation and differentiation ability of DPSC.

To carry out the experiments was used the TS/S method, which is well established as an efficient model to evaluate the proliferation and differentiation rates of stem cells from dental tissues $(10,18)$. Furthermore, Demarco et al. (10) has shown that the TS/S is useful to evaluate physical properties of the scaffolds. Comparing two PLLA scaffolds with different porous formats (spherical $x$ cubic), they were able to show that both porogens provided an adequate environment for DPSC proliferation and differentiation (positive for MEPE, DMP1 and DSPP). Thus, it was tested 
whether the same pore size (251-425 $\mu \mathrm{m})$ tested before (10), and a smaller one could had some influence on the DPSC proliferation and differentiation, since it was previously reported that smaller porous sizes increased the specific surface area for cell attachment, which influences directly the RCD (22).

To evaluate RCD, the 4-[3-(4-Iodophenyl)-2-(4nitrophe-nyl)-2H5tetrazolio]-1,3-benzene disulfonate, WST-1 test was applied, which has been reported as an effective tool to determine the proliferation rates of DPSC (21). Tetrazolium salt-based methods, such as WST-1 are simple and efficient procedures to analyze the DPSC proliferation based on cell metabolism. In such methods, the specific tetrazolium salt, a yellow reagent, is metabolically reduced by the cell machinery into a bright purple colored formazan salt end-product (23). Thus, a spectrophotometer is used to quantify the intensity of the color, producing numerical data (absorbance) that correlate with the number of metabolically active cells (21). Here, WST-1 test showed an increase in RCD (Fig. 2) with time, until DPSC reached confluence or differentiation occurred in both evaluated pore ranges. This shows that the different evaluated scaffolds were sufficiently permeable enabling cell growth, migration and nutrition. Nevertheless, a significant difference in RCD was observed at day 14 . In such specific time point, the DPSC seeded in the scaffolds with larger pores (251-425 $\mu \mathrm{m})$ showed a higher proliferation rate than those seeded in the scaffolds with smaller pores.

From these data, it was hypothesized that higher pore size (HPS) allowed a faster DPSC migration and proliferation, which allowed the DPSC reach the confluence faster than cells seeded into scaffolds with smaller pores (SPS). Murphy et al. (14) comparing a range of scaffolds with different pore sizes, showed that larger pore size is able to improve cellular adhesion and infiltration into scaffolds up to 7 days post-seeding. However, those results were obtained in a series of collagen-glycosaminoglycan (CG) scaffolds. It is well established that cells can discriminate subtle changes

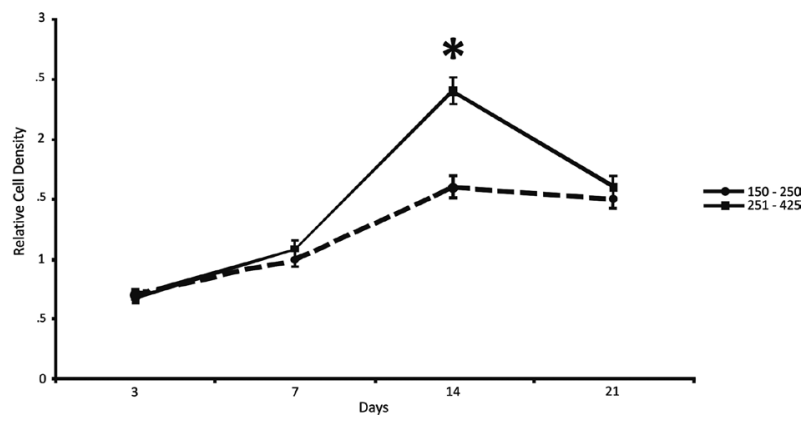

Figure 2. WST- 1 analysis demonstrating the RCD rates produced on the two scaffolds. Day 14 ( $<<0.05)$. in the ECM and it affects their behavior (12); therefore, the results should be compared with caution. In addition, a consistent slowdown was observed in total RCD at day 21 into HPS, similar to the one observed in the SPS. In an attempt to explain it, two hypotheses were raised: 1) cells had reached confluence into TS/S with large pores after day $14 ; 2$ ) higher cell densities, provided by larger mean pores, inhibited the proliferation by cell-cell contact and it was accentuated by the crowding space, which induces a morphologic alteration in cells and could induce cell death (24). It is interesting to point out that scaffold pore size affects other stem cells' behavior behind RCD. In this context, deep analyses should be carried out because other variables can be responsible for cell density decrease.

In the present study, it was not possible to observe a statistical difference in RCD when DPSC were seeded into the both tested scaffolds. Therefore, it was hypothesized that the theoretically faster cell proliferation provided by the larger pores overlaid the benefits provided by the major specific area in the scaffolds with smaller pores (14).

The scaffolds' volume should be taken into account to evaluate the stem cell proliferation based on TE principles $(1,10,13)$. When slices from different teeth are used, clearly the pulp chamber volume will vary. In the TS/S model, the scaffold is produced in a direct way inside the pulp chamber from human teeth (10). The anatomical variation inherent for each tooth could produce a bias when carrying out the evaluation of cell proliferation by applying colorimetric tests, like WST-1, since this tool is influenced by the number

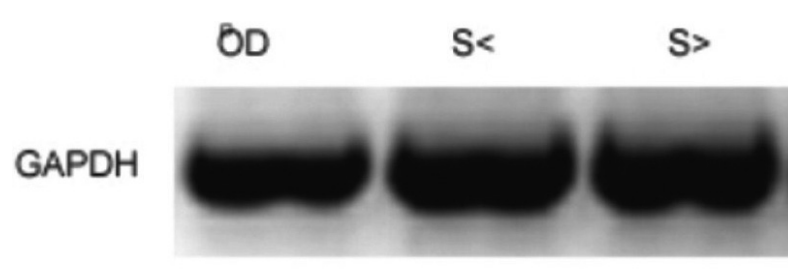

DSPP

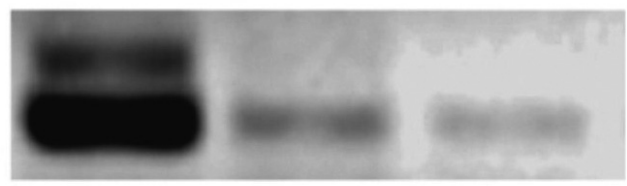

MEPE

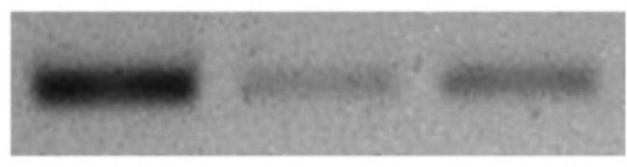

DMP1

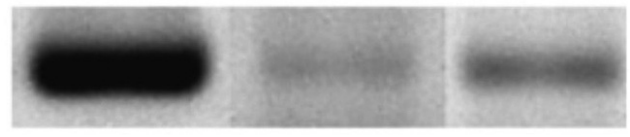

Figure 3. RT-PCR analysis showing that the DPSC were able to express the odontoblast markers after have being seeded for 21 days into both scaffolds. OD=0dontoblastic RNA; $\mathrm{S}<=$ Scaffolds with minor pore size; $S>=$ Scaffolds with larger pore size. GAPDH: Housekeeping gene. 
of cells in the scaffold (21). To minimize such bias, the teeth used in the present study were standardized. To be included here all teeth should have similar characteristics (erupted third molar from young patients). Using a digital caliper, the largest rays of the pulp chamber were measured in two axes (Fig. 1). Thus, a constant measures were obtained - the tooth slice thickness $(1 \mathrm{~mm})$ and the two major widths of pulp chamber - and these values were standardized, allowing the maximum of $10 \%$ variation between the chamber sizes among specimens in the tested groups.

To assess the differentiation of DPSC in odontoblastlike genotype was evaluated the relative gene expression of DSPP, DMP-1 and MEPE using the RT-PCR based on a previous study (20). After 21 days, DPSC in both HPS and SPS were able to express the three putative odontoblast markers into TS/S as previously reported in other studies $(10,18,25)$. RT-PCR showed that the evaluated pore sizes did not influence the odontoblast markers expression. Using the TS/S, the process of PLLA scaffold degradation should be considered; due to lactic acid release and a possible acidification of the environment would impair the expression of DSPP, DMP-1 and MEPE. However, in a previous work (10) was evaluated the expression of the above-mentioned genes in vitro and in vivo, and the results obtained showed that the PLLA scaffolds did not impair the odontoblast markers expression and formation of pulp-like tissue in vivo. As matter of fact, scaffold degradation is a prerequisite to accomplish differentiation of stem cells towards odontoblastic-like genotype (10). The products of PLLA scaffold degradation, instead of disturbing the stem cell differentiation contributed to the dentin solubilization of growth factors, which in turn have acted as morphogenic agents to direct DPSC or SHED differentiation towards an odontoblast-like genotype.

Within the limitations of this study, it was possible to conclude that the two ranges of pore sizes evaluated in this study provided a favorable environment for DPSC proliferation and differentiation, with overall similar results between them.

Every knowledge generated about biomaterials (scaffolds) coupled with advances in clinical research, will provide tools to translate regenerative pulp therapies into clinical dental practice.

\section{Resumo}

0 objetivo desse estudo foi avaliar a influência do tamanho dos poros de um scaffold à base de poli ácido láctico (PLLA) sobre a proliferação e diferenciação de células tronco da polpa dental (dental pulp stem cells DPSC). Os scaffolds foram preparados dentro da câmara pulpar de discos de terceiros molares $(1 \mathrm{~mm})$, utilizando sal como porógeno (150-250 $\mu \mathrm{m}$ ou 251-450 $\mu \mathrm{m})$. DPSC ( $1 \times 10^{5}$ células) foram semeadas nos scaffolds com diferentes tamanhos de poros e cultivadas em placas de 24 poços. A proliferação celular foi avaliada utilizando WST-1 após 3-21 dias. Além disso, RT-PCR foi utilizado para avaliar a diferenciação odontoblástica das DPSC utilizando marcadores da diferenciação odontoblástica (DSPP, DMP-1 e MEPE). RNA obtido de odontoblastos humanos foi utilizado como controle. A taxa de proliferação celular foi semelhante nos dois scaffolds avaliados, exceto no $14^{\circ}$ dia, no qual as células cultivadas nos scaffolds com os maiores poros apresentaram uma maior taxa de proliferação $(p<0,05)$. Após 21 dias, as DSPC cultivadas em ambos scaffolds avaliados foram capazes de expressar os marcadores odontoblásticos DMP-1, DSPP e MEPE. Em resumo, ambos scaffolds avaliados nesse estudo permitiram a proliferação e diferenciação odontoblástica das DPSC.

\section{Acknowledgements}

The study was funded by grant R01-DE21410 from the NIH/NIDCR (JEN). The authors would also like to ackowledge the Brazilian Government (\# 080/2009/DPB-CAPES) for the scholarship provided to the first author (MCMC).

\section{References}

1. Demarco FF, Conde MC, Cavalcanti BN, Casagrande L, Sakai VT, Nor JE. Dental pulp tissue engineering. Braz Dent J 2011;22:3-13.

2. Baldissera EZ, Silva AF, Gomes AP, Etges A, Botero T, Demarco FF, et al.. Tenascin and fibronectin expression after pulp capping with different hemostatic agents: preliminary study. Braz Dent J 2013;24:188-193.

3. Bjorndal L, Mjor IA. Pulp-dentin biology in restorative dentistry. Part 4: Dental caries - characteristics of lesions and pulpal reactions. Quintessence Int 2001;32:717-736.

4. Heyeraas KJ, Sveen OB, Mjor IA. Pulp-dentin biology in restorative dentistry. Part 3: Pulpal inflammation and its sequelae. Quintessence Int 2001;32:611-625.

5. Friedman $\mathrm{S}$, Mor $\mathrm{C}$. The success of endodontic therapy - healing and functionality. J Calif Dent Assoc 2004;32:493-503.

6. Nor JE. Tooth regeneration in operative dentistry. Oper Dent 2006;31:633-642.

7. Moreno-Hidalgo MC, Caleza-Jimenez C, Mendoza-Mendoza A, IglesiasLinares A. Revascularization of immature permanent teeth with apical periodontitis. Int Endod J 2014;47:321-331.

8. Dantas RV, Conde MC, Sarmento HR, Zanchi CH, Tarquinio SB, Ogliari $F A$, et al.. Novel experimental cements for use on the dentin-pulp complex. Braz Dent J 2012;23:344-350.

9. Langer R, Vacanti JP. Tissue engineering. Science 1993;260:920-926.

10. Demarco FF, Casagrande L, Zhang Z, Dong Z, Tarquinio SB, Zeitlin BD, et al.. Effects of morphogen and scaffold porogen on the differentiation of dental pulp stem cells. J Endod 2010;36:1805-1811.

11. Goldberg M, Smith AJ. Cells and extracellular matrices of dentin and pulp: a biological basis for repair and tissue engineering. Crit Rev Oral Biol Med 2004;15:13-27.

12. Lawrence BJ, Madihally SV. Cell colonization in degradable 3D porous matrices. Cell Adh Migr 2008;2:9-16.

13. Santana BP, Paganotto GF, Nedel F, Piva E, de Carvalho RV, Nor JE, et al.. Nano/microfiber scaffold for tissue engineering: physical and biological properties. J Biomed Mater Res A 2012;100;3051-3058.

14. Murphy $C M$, Haugh MG, O'Brien FJ. The effect of mean pore size on cell attachment, proliferation and migration in collagenglycosaminoglycan scaffolds for bone tissue engineering. Biomaterials 2010;31:461-466.

15. Zeltinger J, Sherwood JK, Graham DA, Mueller R, Griffith LG. Effect of pore size and void fraction on cellular adhesion, proliferation, and matrix deposition. Tissue Eng 2001;7:557-572.

16. Salem AK, Stevens R, Pearson RG, Davies MC, Tendler SJ, Roberts CJ, et al.. Interactions of $3 \mathrm{~T} 3$ fibroblasts and endothelial cells with defined pore features. J Biomed Mater Res 2002;61:212-217.

17. Karageorgiou V, Kaplan D. Porosity of 3D biomaterial scaffolds and osteogenesis. Biomaterials 2005;26:5474-5491.

18. Casagrande $L$, Demarco FF, Zhang Z, Araujo FB, Shi S, Nor JE. Dentin-derived BMP-2 and odontoblast differentiation. J Dent Res 2010;89:603-608.

19. Lu L, Peter SJ, Lyman MD, Lai HL, Leite SM, Tamada JA, et al.. In vitro and 
in vivo degradation of porous poly(DL-lactic-co-glycolic acid) foams. Biomaterials 2000;21:1837-1845.

20. Conde MC, Nedel F, Campos VF, Smith AJ, Nor JE, Demarco FF, et al.. Odontoblast RNA stability in different temperature-based protocols for tooth storage. Int Endod J 2012;45:266-272.

21. Nedel F, Soki FN, Conde MC, Zeitlin BD, Tarquinio SB, Nor JE, et al.. Comparative analysis of two colorimetric assays in dental pulp cell density. Int Endod J 2011;44:59-64.

22. El-Backly RM, Massoud AG, El-Badry AM, Sherif RA, Marei MK. Regeneration of dentine/pulp-like tissue using a dental pulp stem cell/ poly(lactic-co-glycolic) acid scaffold construct in New Zealand white rabbits. Aust Endod J;2008;34:52-67.

23. Berridge $M$, Tan A, McCoy $K$, Wang R. The biochemical and cellular basis of cell proliferation assays that use tetrazolium salts. Biochemica 1996;4:14-19.

24. Lanosa XA, Colombo JA. Cell contact-inhibition signaling as part of wound healing processes in brain. Neuron Glia Biol 2008;4:27-34.

25. Sakai VT, Zhang Z, Dong Z, Neiva KG, Machado MA, Shi S, et al.. SHED differentiate into functional odontoblasts and endothelium. J Dent Res 2010;89:791-796.
Received March 25, 2014 Accepted December 16, 2014 